\title{
Review of Peter Singer's Ethics in the real world: 82 brief essays on things that matter. Princeton: Princeton University Press, 2016, 355 pp.
}

\author{
JEROEN HOPSTER \\ Utrecht University
}

Ethics in the real world is a collection of short essays, columns, and opinion pieces written by philosopher Peter Singer between 2001 and 2016. Each of the pieces constitutes a short chapter, in which Singer reflects on pressing moral and social issues. Many of these issues are familiar from Singer's previous work. They include animal suffering and the ethics of eating meet (do we have a moral duty to become vegans?), the sanctity of life (under what conditions are abortion and euthanasia morally permissible?), public healthcare (should we attempt to prolong a person's life at all costs?), sex and gender (should incest be criminalized?), doing good and effective altruism (can there be such a thing as evidence-based charity?), politics and global governance (will polluters pay for climate change?), and science and technology (is resistance against genetically modified organisms warranted?).

Apart from a short introduction and some added postscripts, all of the book's pieces have been published before. To read a book with this format-an ensemble of earlier-published opinion pieces, on a diversity of topics and aimed at a general audience-might seem like browsing over a page-a-day calendar. It is to Singer's merit that reading his book is a worthwhile endeavor, in spite of its lack of novelty and the format's inherent limitations. Singer is a provocative, well-informed and hands-on philosopher, with a lucid and engaging writing style. The collection provides a comprehensive and accessible overview of themes that are central to Singer's ethics. It will specifically be of interest to those not yet acquainted with his work, but may appeal to anyone with an interest in applied ethics and social policy.

Rather than summarizing each of its 82 chapters, in what follows I make three general observations about the book. The first observation concerns Singer's engagement with public philosophy, the second his use of methods in applied ethics and the third the distinctively 
cosmopolitan character of Singer's utilitarianism. I conclude with a remark about the societal relevance of applied philosophy.

Singer's essay collection belongs to the tradition of public philosophy - that is, the tradition of doing philosophy in public, nonacademic settings. The topics he addresses and the terms in which he frames them are meant to appeal to a general audience. He notes, sarcastically, that

[t]here is a view in some philosophical circles that anything that can be understood by people who have not studied philosophy is not profound enough to be worth saying. To the contrary, I suspect that whatever cannot be said clearly is probably not being thought clearly either (p. x).

Indeed, insofar as popularizing is a matter of style, Singer succeeds admirably: his essays are well-structured, engaging, and exemplarily clear. Moreover, his arguments tend to be nuanced and non-dogmatic, in spite of his well-known ethical agenda: here is an ethicist not looking for arguments to support a preconceived conclusion, but sincerely pondering the implications of his utilitarian stance. A disadvantage of the book's short chapters is that the lack of scholarly detail does, occasionally, preclude the level of discussion that a topic calls for. This struck me, for instance, in Singer's defense of the late Derek Parfit's metaethical objectivism: a thousand words treatment simply does not suffice to touch upon the intricacies of the metaethical debate.

A second observation about Singer's approach concerns his extensive engagement with numbers, statistics, and matters of fact. Much of our ethical behavior takes place in a face of uncertainty, and weighing the moral importance of any given issue can be a difficult task; numbers, however, often provide us with a rough indication of moral weight, or so Singer suggests. "I would rather be vaguely right than precisely wrong", John Maynard Keynes once noted. Singer cites him approvingly: the big picture is what matters, and numbers and statistics are invaluable to get a hold on it. For example, in the chapter If fish could scream, Singer highlights the staggering number of fish on which humans inflict death: somewhere in between 1 and 2.7 trillion every year. In the chapter The real abortion tragedy, Singer notes that 86 percent of all abortions occur in the developing world. In A case for veganism, Singer emphasizes the wastefulness of modern industrial animal production: pig farms use six pounds of grain for every pound of 
boneless meat they produce. Numbers such as these help us, inter alia, to set our ethical priorities.

"We must make policies for the real world, not an ideal one", Singer (p. 112) argues. In the real world facts matter and numbers count. Psychologically, we tend to be more easily moved to help one specific individual rather than an anonymous multitude. Helping the multitude, however, has greater moral importance, or so Singer maintains. This type of argument-related to so-called "evolutionary debunking arguments"-comes up on several occasions: Singer picks out the morally salient features of a situation, and emphasizes that our intuitions are misled with regard to them. Another instrument central to his applied ethics toolkit is reasoning by analogy. Oftentimes, Singer's baseline for judging whether a morally controversial policy is justified is to take a less controversial case, and to argue that both cases are analogous.

A final observation about Singer's approach is his thorough cosmopolitanism. The fact that we are globally connected holds implications for many of Singer's ethical views. For instance, he criticizes the enormous expenditures on works of art, both with private and public money, by stressing that meanwhile people in Africa are dying from malaria. In and by itself there is nothing wrong with spending money on art, but the fact that this money could also be spent for different purposes changes the ethical playing field. Singer's utilitarianism leads to a holistic outlook, in which all actions are morally laden. To take a transatlantic flight is to contribute substantially to $\mathrm{CO}_{2}$ emissions; to invest money in high-price art is to refrain from investing the same money to help the global poor. According to Singer (p. 161), "those who have enough to spend on luxuries, yet fail to share even a tiny fraction of their income with the poor, must bear some responsibility for the deaths they could have prevented". Note that a "tiny fraction" of one's income is much less than what Singer has previously argued that should be given away to charity. A sense of realism about what people, in general, can be expected to contribute, guides Singer's proposal here; small donations constitute the bare minimum of what one must do to lead a morally decent life, he submits. To lead a morally exemplary life, however, more work is required.

For readers familiar with Singer's work these ideas are not new. For those who are not, on the other hand, they are likely to offer an original perspective that may leave a lasting imprint. Myself, I feel better 
informed about a variety of social issues, and have slightly shifted my perspective about some of them, after having read this book. Precisely this power to shift people's opinion about urgent ethical matters is what gives philosophy its social relevance, Singer (p. 37) submits. "I know from my own experience that taking a course in philosophy can lead students to turn vegan, pursue careers that enable them to give half their income to effective charities, and even donate a kidney to a stranger", he recounts. "How many other disciplines can say that?"

Jeroen Hopster is a $\mathrm{PhD}$ candidate in the NWO-funded program "Evolutionary Ethics" at Utrecht University. At present he is a visiting fellow at Harvard University. He is an editor of the Dutch philosophy journal Wijsgerig Perspectief and a regular contributor to Filosofie Magazine. He has published on objectivity in ethics and has co-authored a book on Buddhist philosophy (Boeddhisme voor denkers, Ten Have 2014; Bouddha philosophe, L'Iconoclaste 2016).

Contact e-mail: <j.k.g.hopster@uu.nl>

Website: <http://www.jeroenhopster.com> 